\title{
Handling culture medium composition for optimizing plant cell suspension culture in shake flasks
}

\author{
Tiago Fidemann ${ }^{1} \cdot$ Gabriela Aparecida de Araujo Pereira ${ }^{1} \cdot$ Tárik Reis Heluy $^{1} \cdot$ Rodrigo Boccoli Gallego $^{1}$. \\ Mônica Rosa Bertão ${ }^{1}$. Regildo Márcio Gonçalves da Silva ${ }^{2} \cdot$ Eutimio Gustavo Fernández Núñez $z^{3}$ (])
}

Received: 16 September 2017 / Accepted: 6 December 2017 / Published online: 12 December 2017

๑) Springer Science+Business Media B.V., part of Springer Nature 2017

\begin{abstract}
This work aimed to optimize statistically the culture medium composition for cell plant suspension culture using as a model Capsicum baccatum L. var. pendulum cells. The cell growth was maximized as well as the secondary metabolite yields with antioxidant activity, which could find applications in pharmaceutical and food industries. A Box-Behnken statistical design was utilized to optimize the basal Murashige and Skoog medium, which is widely used in plant cell culture. Three relevant ingredients, saccharose (A, 15-45 $\left.\mathrm{g} \mathrm{L}^{-1}\right), \mathrm{KH}_{2} \mathrm{PO}_{4}\left(\mathrm{~B}, 0.085-0.255 \mathrm{~g} \mathrm{~L}^{-1}\right)$ and $\mathrm{KNO}_{3}\left(\mathrm{C}, 0.95-2.85 \mathrm{~g} \mathrm{~L}^{-1}\right)$ were considered. The cell growth index as well as antioxidant activity, total phenolic compounds and flavonoids from dry extracts (DE) derived of cell cultures, were determined. Growth index (GI) and flavonoids content (F) were sensitive to the changes in nutrient composition in culture medium, and they were modeled statistically according to modified quadratic $(\mathrm{GI}=1.76+0.59 \mathrm{~A}-0.32 \mathrm{~B}-0.42 \mathrm{AC})$ and two-factor interaction $(\mathrm{F}(\mathrm{mg}$ of rutin $/ \mathrm{g} \mathrm{DE})=0.88+0.35 \mathrm{AC}-0.29 \mathrm{BC})$ models, respectively. Antioxidant activity and total polyphenols were independent of the nutrient concentrations within the range under study. The optimized culture medium composition was defined for two approaches: maximization of the cell growth ( $45 \mathrm{~g} \mathrm{~L}^{-1}$ saccharose, $0.09 \mathrm{~g} \mathrm{~L}^{-1} \mathrm{KH}_{2} \mathrm{PO}_{4}, 0.95 \mathrm{~g} \mathrm{~L}^{-1} \mathrm{KNO}_{3}$ ) and maximization of flavonoids production $\left(45 \mathrm{~g} \mathrm{~L}^{-1}\right.$ saccharose, $0.09 \mathrm{~g} \mathrm{~L}^{-1} \mathrm{KH}_{2} \mathrm{PO}_{4}, 2.85 \mathrm{~g} \mathrm{~L}^{-1} \mathrm{KNO}_{3}$ ). According to the current results, other elicitation strategies should be assessed to make this bioprocess more efficient for manufacturing secondary metabolites with antioxidant activity from suspension culture of Capsicum baccatum L. var. pendulum cells.
\end{abstract}

Keywords Bioprocess optimization · Capsicum baccatum L. var. pendulum · Plant cell culture · Polyphenolic compounds · Suspension culture

Communicated by Sergio J. Ochatt.

Eutimio Gustavo Fernández Núñez

eutimiocu@yahoo.com

1 Laboratório de Biotecnologia Vegetal, Departamento de Biotecnologia, Universidade Estadual Paulista - UNESP, Campus-Assis, Avenida Dom Antônio, 2100, Assis, SP 19806-900, Brazil

2 Laboratório de Fitoterápicos e Produtos Naturais (FITOLAB), Departamento de Biotecnologia, Universidade Estadual Paulista - UNESP, Campus-Assis, Avenida Dom Antônio, 2100, Assis, SP 19806-900, Brazil

3 Centro de Ciências Naturais e Humanas (CCNH), Universidade Federal do ABC, Avenida dos Estados, 5001, Santo André, SP 09210-580, Brazil

\section{Introduction}

Plant-derived compounds form a significant slice of economically important pharmaceuticals (taxol, ginsenosides, artemisinin, etc.), food additives (flavors, fragrances, and colorants) and agrochemicals (biopesticides) in the current societies from over the world. Most of these active ingredients are classified as secondary metabolites. Part of them are irrelevant by-products of metabolic routes due to indistinct enzyme activity, while some do have a remarkable role in the interaction of the plant with its environment, thus can be considered biologically active (Zhou and Zhong 2010b).

The production of secondary metabolites is often low, less than $1 \%$ dry weight, and depends on the plant species, plant's physiological and development stage as well as environmental factors (Zhou and Zhong 2010b; Wilson and Roberts 2012). Due to the limited availability of these 
compounds and the difficulties to set a robust commercial process for them from natural sources, other technological platforms have been explored such as chemical synthesis, heterologous production (bacteria, yeast, and alternatives plant species) and plant cell culture (Wilson and Roberts 2012). Specifically, plant cell culture is an attractive source for production of high-value secondary metabolites with complex chemical structures (Davies and Deroles 2014).

Plant cells are biosynthetically totipotent, which means that each cell in culture retains entire genetic information, consequently its ability to produce the spectrum of chemicals found in the parent plant. However, there exist still troubles in the production of metabolites by cell cultures because of the instability of cell lines, low yields, slow growth and scale-up problems (Ramachandra Rao and Ravishankar 2002; Wilson and Roberts 2012).

Among the strategies to make efficient the secondary metabolite production in technologies based on plant cell culture, the manipulation of growing conditions is one of the most fundamental approaches (Smetanska 2008). Many chemical and physical factors, such as media components, $\mathrm{pH}$, temperature, and light, affect the yield of secondary metabolites in this biotechnology. Specifically, there are several reports of how the application of nutrient stress to plant-cell and tissue culture can reduce growth and primary metabolism and promote differentiation and secondary metabolism. As a rule, plant cell culture media include inorganic components (macroelements and microelements), organics (saccharose) and phytohormones. Thus, a suitable handling of concentrations for these three categories of components in the culture medium can improve the bioprocess productivity (Yeoman and Yeoman 1996; Smetanska 2008).

On the other hand, peppers, as are well-known, have a broad spectrum of secondary metabolites with antioxidant properties and can be a suitable alternative to obtain these chemicals. This class of compounds is extremely useful to minimize or control critical health disorders such as diabetes, cancer, cardiovascular and neurodegenerative diseases. Among the peppers, the Capsicum genus, which is native to the tropical zones of Central and South America, stands out. It includes an enormous variety of species with many fruit's shapes, sizes, and flavors, having significant economic and cultural values. Capsicum baccatum is one of five main domesticated pepper species, in which also include Capsicum annuum, Capsicum chinense, Capsicum frutescens, and Capsicum pubescens (Lannes et al. 2007; Zimmer et al. 2012). Specifically, plant cell culture approaches involving $C$. annuum, $C$. chinense, and $C$. frutescens species have been deeply assessed to obtain beneficial health compounds like capsaicinoids (Prasad et al. 2006; Ferri et al. 2017). However, equivalent studies including $C$. baccatum species are scarce. Our group has been recently focused on the initial in vitro culture steps (in vitro germination and callus culture) for obtaining antioxidant compounds from $C$. baccatum species (Fidemann et al. 2016, 2017).

This work aimed to optimize statistically the culture medium composition for suspension culture of Capsicum baccatum $\mathrm{L}$. var. pendulum cells to maximize the cell growth and the yield of secondary metabolites with antioxidant activity, which could find applications in pharmaceutical and food industries.

\section{Materials and methods}

\section{Plant material}

The hypocotyl explants were obtained from Capsicum baccatum L. var. pendulum (Cambuci) seedlings in vitro germinated. The seeds were obtained in local markets from Assis, São Paulo State $\left(-22^{\circ} 39^{\prime} 42^{\prime \prime} \mathrm{S},-50^{\circ} 24^{\prime} 44^{\prime \prime} \mathrm{W}\right)$. The voucher specimen (HASSI-01127) was deposited at the Herbarium Assisense of the Biology Department, UNESP, Assis, Brazil. The experiments were performed at Laboratório de Biotecnologia Vegetal, UNESP_FCL, Assis/SP-Brasil.

\section{Callus culture}

The hypocotyl explants (in average $7 \mathrm{mg}$ ) were obtained from seedling (pretreated seeds with $1 \% \mathrm{KNO}_{3}$ aqueous solution (w/v) for $10 \mathrm{~min}$ and in vitro germinated in culture medium containing distilled water, $0.6 \%$ agar, and $1.88 \mathrm{mg} \mathrm{L}^{-1}$ gibberellic acid) with cotyledons appearance. The detailed procedures for the culture initiation were previously reported (Fidemann et al. 2016). With the aid of sterilized tweezers and scissors, explants were cut and inoculated in Petri dishes $(15 \times 100 \mathrm{~mm})$ (five explants per dish) containing $35 \mathrm{~mL}$ Murashige and Skoog culture medium (MS) (pH 5.75) (Murashige and Skoog 1962) solidified with Phytagel (Sigma Chemical Co., St. Louis, MO) $4 \mathrm{~g} \mathrm{~L}^{-1}$, supplemented with $3 \%$ sucrose and 2,4-D/BAP (5:1 ratio) at $1.138 \mathrm{mg} \mathrm{L}^{-1}$ (these conditions were optimized in previous work of our team) (Fidemann et al. 2017). The culture media were previously autoclaved at $121{ }^{\circ} \mathrm{C}, 1 \mathrm{~atm}$ for $20 \mathrm{~min}$. The calluses were removed from Petri dishes for inoculum preparation after 30 days of culture at $30{ }^{\circ} \mathrm{C}$ in darkness.

\section{Inoculum preparation}

A fresh mass of callus to guarantee an initial cell concentration of $12.5 \mathrm{~g} \mathrm{~L}^{-1}$ was utilized for beginning propagation and adaptation of Capsicum baccatum L. var. pendulum cells to suspension culture in Murashige and Skoog culture medium (Murashige and Skoog 1962) supplemented with 2,4-D/BAP (5:1 ratio) at $1.138 \mathrm{mg} \mathrm{L}^{-1}$. The inoculum preparation for experimental design comprised three serial passages, using 
the same initial concentration and culture medium. All the passages were performed in $100 \mathrm{~mL}$ Erlenmeyer flask (cotton plug) with $20 \mathrm{~mL}$ working volume. Each stage lasted 14 days. The cell separation over the course of inoculum preparation was done by sedimentation.

\section{Optimization of culture medium composition}

The optimization of the modified Murashige and Skoog culture medium (Murashige and Skoog 1962) supplemented with 2,4-D (1.138 $\left.\mathrm{mg} \mathrm{L}^{-1}\right)$ and BAP $\left(0.228 \mathrm{mg} \mathrm{L}^{-1}\right)$ for suspension cell culture of Capsicum baccatum L. var. pendulum was focused on carbon, phosphorus, nitrogen and potassium sources. Three ingredients were considered, saccharose (15-45 $\left.\mathrm{g} \mathrm{L}^{-1}\right), \mathrm{KH}_{2} \mathrm{PO}_{4}\left(0.085-0.255 \mathrm{~g} \mathrm{~L}^{-1}\right)$ and $\mathrm{KNO}_{3}\left(0.95-2.85 \mathrm{~g} \mathrm{~L}^{-1}\right)$; their concentrations were studied in $\pm 50 \%$ range, taking as a reference the standard concentration of each ingredient in Murashige and Skoog culture medium.

A Box-Behnken statistical design with three repetitions of the central point in the experimental domain was utilized to optimize the culture medium (Table 1). The Box-Behnken designs are second-order designs, which require fewer factor levels and experiments than other experimental designs utilized to determine optimal conditions (Chen et al. 2006). Thus, this statistical approach was chosen based on experimental economic issues. Fifteen runs were performed at $28 \pm 1^{\circ} \mathrm{C}$ in

Table 1 Box-Behnken experimental design to define de culture medium composition for suspension culture of Capsicum baccatum L. var. pendulum cells to maximize and model the yield of secondary metabolites with antioxidant activity

\begin{tabular}{llll}
\hline \multirow{2}{*}{ Run } & \multicolumn{3}{l}{ Concentrations of culture medium ingredient $\left(\mathrm{g} \mathrm{L}^{-1}\right)$} \\
\cline { 2 - 4 } & Saccharose & $\mathrm{KH}_{2} \mathrm{PO}_{4}$ & $\mathrm{KNO}_{3}$ \\
\hline $1^{\mathrm{a}}$ & 30 & 0.170 & 1.90 \\
2 & 30 & 0.255 & 0.95 \\
$3^{\mathrm{a}}$ & 30 & 0.170 & 1.90 \\
4 & 15 & 0.085 & 1.90 \\
5 & 30 & 0.255 & 2.85 \\
$6^{\mathrm{a}}$ & 30 & 0.170 & 1.90 \\
7 & 15 & 0.170 & 2.85 \\
8 & 45 & 0.255 & 1.90 \\
9 & 30 & 0.085 & 2.85 \\
10 & 15 & 0.170 & 0.95 \\
11 & 45 & 0.085 & 1.90 \\
12 & 45 & 0.170 & 2.85 \\
13 & 30 & 0.085 & 0.95 \\
14 & 45 & 0.170 & 0.95 \\
15 & 15 & 0.255 & 1.90 \\
\hline
\end{tabular}

${ }^{a}$ Experimental combinations including the typical concentrations of saccharose, $\mathrm{KH}_{2} \mathrm{PO}_{4}$, and $\mathrm{KNO}_{3}$ in the MS basal medium (control treatment, or central point in the experimental domain) darkness. The inoculated dry cell mass guaranteed an initial cell concentration equal to $0.76 \mathrm{~g} \mathrm{~L}^{-1}$. The agitation speed was $100 \mathrm{rpm}$. The cell cultures were performed in $100 \mathrm{~mL}$ Erlenmeyer flask (cotton plug) with $15 \mathrm{~mL}$ working volume.

The end of suspension cell culture for all experimental runs was set on fifteenth day after inoculation. The culture was monitored by dissimilation curve method, which was defined previously by Schripsema et al. (1990).

\section{Quantification of dry cell mass, extracts obtaining and growth index}

The wet cells from each Erlenmeyer flask (corresponding to the run of experimental design) at the end of culture were separated by sedimentation, frozen and lyophilized (LIOBRAS, model Loitop L101, São Carlos, Brazil) (24-36 h) to obtain the dry mass. The dry cell mass was measured in analytical balance. Then it was macerated with $\mathrm{N}_{2(1)}(77 \mathrm{~K})$ to obtain the vegetable powder. The solutions were prepared in the ratio of $5 \mathrm{mg}$ (powder) per $1 \mathrm{~mL}$ in ethanol $70 \%$ (v/v). Then, they were put in an ultrasound bath $(7 \mathrm{~min}$ at $30 \mathrm{KHz})$, and hereafter were centrifuged for $15 \mathrm{~min}$ at $2000 \mathrm{rpm}$ (QUIMIS, centrifugal microprocessor, model: Q222TM216, Diadema, Brazil). The supernatant was used for the chemical assays. The growth index was defined as the ratio between the dry cell mass at the end $\left(D M_{\text {end }}\right)$ of culture respect to equivalent mass at the inoculation moment $\left(D M_{\text {inoculation }}\right)$ (Eq. 1).

Growth index $=\frac{D M_{\text {end }}}{D M_{\text {inoculation }}}$

\section{In vitro antioxidant activity}

The in vitro antioxidant activity was determined using the 1,1-diphenyl-2-picrylhydrazyl (DPPH) methodology described by Blois (1958) with modifications. In each tube was added absolute ethanol, acetate buffer (100 mM pH 5.5), ethanolic solution of DPPH $(500 \mu \mathrm{M})$ and the sample. The control tube was done excluding the sample addiction. The reaction mixtures were stirred by vortex and kept in the dark for $30 \mathrm{~min}$. The absorbance was measured using a Femto-600 Plus UV/Vis spectrophotometer (São Paulo, Brazil) at $517 \mathrm{~nm}$. The samples quantifications were done in triplicate to guarantee statistical robustness of the results and the absorbance values were expressed as percentage by the following Eq. (2):

$\% A A=\left[\frac{\left(A_{c}-A_{S}\right)}{A_{C}}\right] \times 100$

where $\% \mathrm{AA}$ is the antioxidant activity, $\mathrm{A}_{\mathrm{C}}$ is the control absorbance and $A_{S}$ is the sample absorbance. 


\section{Total phenol and flavonoid assays}

The content of total phenolic compounds was quantified using the Folin-Ciocalteu colorimetric method modified by Singleton and Rossi (1965). A reaction mixture containing extract (ethanol 70\%) was added distilled water and Folin-Ciocalteu reagent. After $3 \mathrm{~min}$, saturated $\mathrm{Na}_{2} \mathrm{CO}_{3}$ solution was added, and the mixture was kept standing for $60 \mathrm{~min}$. The absorbance was measured using a Femto-600 Plus UV/Vis spectrophotometer (Femto, São Paulo, Brazil) at $765 \mathrm{~nm}$. The samples were run in triplicate for statistical analyses, and the results expressed as milligram gallic acid equivalent (GAE) per gram of dry weight of extract (mg of GAE/g DE).

The total flavonoids content was determined by Vis spectrophotometry, and the samples prepared based on flavonoids complexation with $\mathrm{AlCl}_{3}$ as the colorimetric method described by Zhishen et al. (1999). A reaction mixture containing extract (ethanol 70\%) was added distilled water and $5 \%$ (w/v) $\mathrm{NaNO}_{2}$ solution. After 6 min, $10 \%$ (w/v) $\mathrm{AlCl}_{3} /$ $\mathrm{H}_{2} \mathrm{O}$ solution and $1 \mathrm{M} \mathrm{NaOH}$ solution were added. Then the reaction mixtures were stirred by vortex and kept standing for $15 \mathrm{~min}$. The absorbance was measured using a Femto600 Plus UV/Vis spectrophotometer at $510 \mathrm{~nm}$. The samples were also run in triplicate, and the results expressed as the rutin equivalent per gram of dry weight of extract ( $\mathrm{mg}$ of $\mathrm{RU} / \mathrm{g} \mathrm{DE})$.

\section{Statistical analysis}

Experimental planning and data analysis from Box-Behnken design were carried out in Design-Expert software (Trial version 10.0.3.1, Stat-Ease, MN, USA). The level of significance $(\alpha)$ for statistical decisions was 0.05 . The optimization of culture medium composition for maximizing dry cell mass of Capsicum baccatum L. var. pendulum and antioxidant activity associated with the corresponding extracts as well as polyphenolic compounds and flavonoids were done using Derringer and Suich's desirability function (Costa et al. 2011) implemented in the same software.

\section{Results and discussion}

Among phenolic extracts and compounds with antioxidant, antimicrobial and cytotoxic activities, produced by plant cell culture, the anthocyanin extracts, betalains, phenolic acids, and flavonoids have been more extensively studied (Dias et al. 2016). On the other hand, peppers (Capsicum) are good sources of this kind of phytochemicals as well as capsaicinoids, which are strong antioxidants and play a central role in the prevention of cardiovascular disease, cancer and neurological disorders (Loizzo et al. 2015). Thus, we herein focused on the establishment of the basis for bioprocess (culture medium optimization) based on Capsicum baccatum $L$. var. pendulum cells to obtain efficiently secondary metabolites of interest.

Table 2 Analysis of the adjusted statistical models regarding coded factors for the four monitored biochemical parameters

\begin{tabular}{|c|c|c|c|c|}
\hline \multirow[t]{2}{*}{ Parameters } & \multicolumn{4}{|l|}{ Response } \\
\hline & Growth index & $\begin{array}{l}\text { Antioxidant activity } \\
(\%)\end{array}$ & $\begin{array}{l}\text { Total polyphenols (mg of } \\
\text { GAE/g DE) }\end{array}$ & Flavonoids (mg of RU/g DE) \\
\hline \multirow[t]{2}{*}{ Model } & Modified quadratic & Mean & Mean & Modified two-factor interaction \\
\hline & Probability values & & & \\
\hline \multicolumn{5}{|l|}{ Statistical test } \\
\hline Model significance & $0.0005^{\mathrm{a}}$ & - & - & $0.0184^{\mathrm{a}}$ \\
\hline Lack of fit & 0.0650 & 0.3754 & 0.6482 & 0.0711 \\
\hline \multicolumn{5}{|l|}{ Model terms } \\
\hline Saccharose (A) & $0.0003^{\mathrm{a}}$ & 0.2950 & 0.8289 & 0.0916 \\
\hline $\mathrm{KH}_{2} \mathrm{PO}_{4}(\mathrm{~B})$ & $0.0183^{\mathrm{a}}$ & 0.2651 & 0.4679 & 0.2957 \\
\hline $\mathrm{KNO}_{3}(\mathrm{C})$ & 0.1877 & 0.1059 & 0.2852 & 0.7601 \\
\hline $\mathrm{AB}$ & 0.1326 & - & - & 0.0956 \\
\hline $\mathrm{AC}$ & $0.0245^{\mathrm{a}}$ & - & - & $0.0247^{\mathrm{a}}$ \\
\hline $\mathrm{BC}$ & 0.9834 & - & - & $0.0497^{\mathrm{a}}$ \\
\hline $\mathrm{A}^{2}$ & 0.0943 & - & - & - \\
\hline $\mathrm{B}^{2}$ & 0.1405 & - & - & - \\
\hline$C^{2}$ & 0.0533 & - & - & - \\
\hline
\end{tabular}

${ }^{a}$ represents the statistically significant model terms 
Four biochemical indexes (growth index, as well as antioxidant activity, total phenolic compounds and flavonoids in extracts) were studied statistically to fulfill the main goal of this research. The results for each of them are discussed below.

\section{Growth index}

One of the most important parameter to characterize the suspension plant cell culture is the growth index. The growth index for Capsicum baccatum $L$. var. pendulum cells was described by a modified quadratic model (Table 2). This biochemical index was influenced positively by saccharose concentration (A) in the culture medium. Contrariwise, the $\mathrm{KH}_{2} \mathrm{PO}_{4}(\mathrm{~B})$ and the two-factor interaction between $\mathrm{A}$ and $\mathrm{KNO}_{3}(\mathrm{C})$ showed an inverse correlation concerning growth index (Eq. 3, the model regarding coded factors).
Growth Index $=1.76+0.59 A-0.32 B-0.42 A C$

The high values $(>2)$ for the growth indexes (Fig. 1a) were associated with culture media containing saccharose in 30-45 $\mathrm{g} \mathrm{L}^{-1}$ concentration range (run numbers $8,9,11$, 13, 14). Specifically, the highest growth index (3.11) was observed for run 11 comprising the maximum saccharose concentration, the lowest $\mathrm{KH}_{2} \mathrm{PO}_{4}$ concentration and the intermediate concentration of $\mathrm{KNO}_{3}$ in the ranges under study (Table 1). In line with this result, the synergistic effect of AC two-factor interaction on growth index was confirmed when high saccharose concentrations are combined with low $\mathrm{KNO}_{3}$ concentrations (Fig. 2). This maximum growth factor for Capsicum baccatum $L$. var. pendulum was like those, previously reported for Capsicum chinense Jacq. in a modified Murashige and Skoog culture medium (Kehie et al. 2016). Also, as the high values of saccharose concentrations ensured high growth indexes, the negative impact of high concentrations of this carbon source on culture medium
Fig. 1 Results of the four monitored biochemical parameters at the end of plant cell culture derived from samples included in the Box-Behnken experimental design (Table 1). a Growth index and flavonoids. b Antioxidant activity and total polyphenols
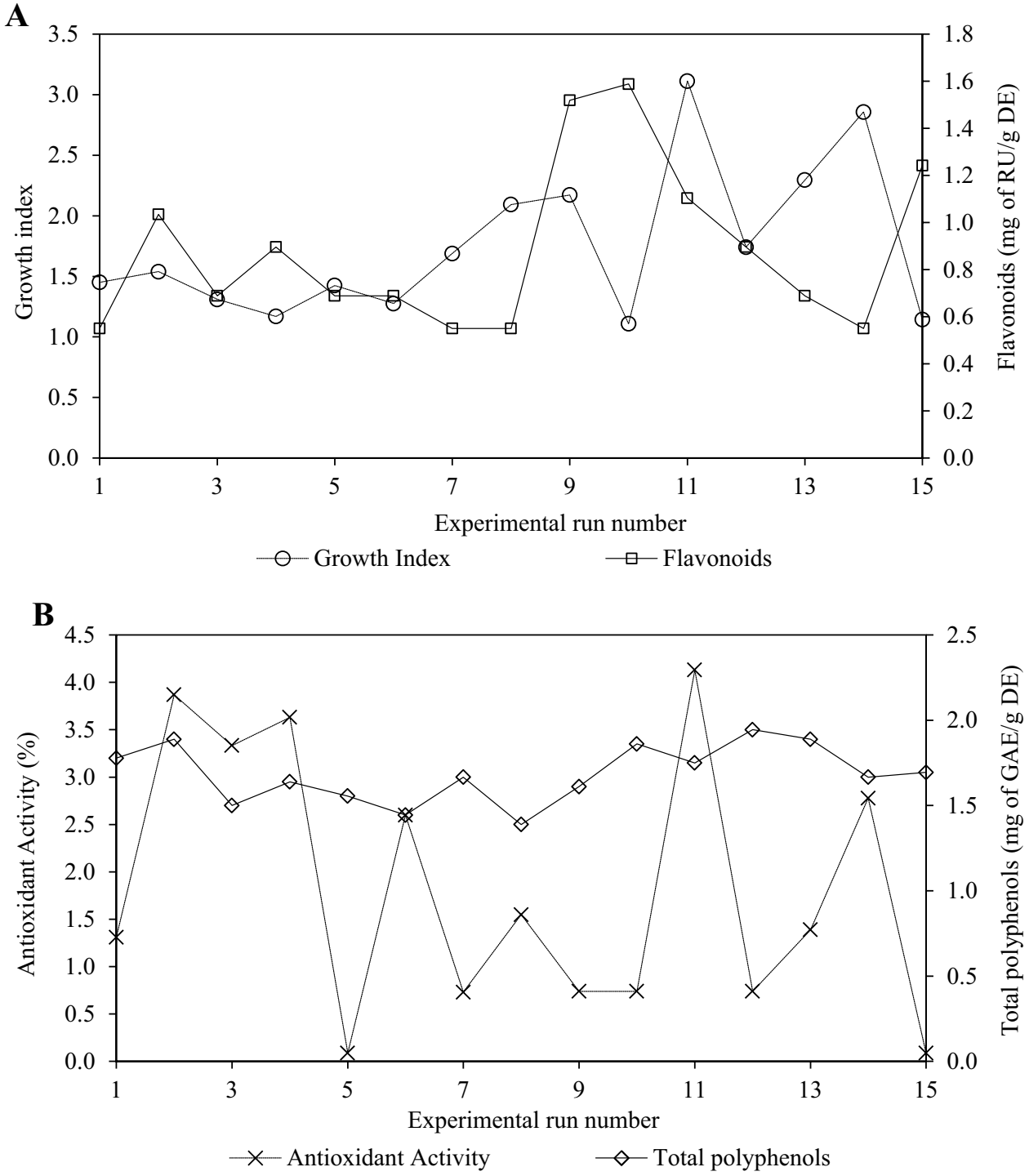
osmolality was not observed for Capsicum baccatum $L$. var. pendulum cells within the saccharose concentration range under study (Murthy et al. 2014).

As a rule, higher levels of phosphate were found to enhance the cell growth (Ramachandra Rao and Ravishankar 2002). This finding was not confirmed in the present work. Probably, this fact occurred because the high phosphate concentrations for these pepper cells were outside of the study range. On the other hand, the confirmed high cell growth at a low concentration of $\mathrm{KNO}_{3}$ could be mainly explained by the major contribution of potassium ion concentration to the osmotic potential, a specific requirement for protein synthesis, and an activator for particular enzyme systems (Zhou and Zhong 2010a).

The weight loss in flasks (dissimilation curves), where plant cell culture is performed, usually correlates well with the cell growth. In the current study, this pattern was not confirmed perfectly. Among the assessed samples with relatively high growth index, just runs 13 and 14 showed high values of weight loss caused by metabolism of sugars $(>1 \mathrm{~g})$ (Fig. 3). The $\mathrm{KNO}_{3}$ concentrations in culture medium associated with both runs were minimum $\left(0.95 \mathrm{~g} \mathrm{~L}^{-1}\right)$ (Table 1). However, four runs $(3,12,13,14)$ with relatively high weight loss corresponded also to culture media comprising saccharose in $30-45 \mathrm{~g} \mathrm{~L}^{-1}$ concentration range. The failure correlation could be caused by significant sugar consumption for cell maintenance (Wilson 1987) in some nutrient arranges and the use of cotton plug as flask stoppers for performing the suspension plant cell culture. The high water evaporation through this stopper has been reported, causing changes in the ratio of water evaporation between flasks (Schripsema et al. 1990).

\section{Antioxidant activity}

The antioxidant activity of the derived extracts from Capsicum baccatum $L$. var. pendulum plant cell culture was independent of the concentrations of the three nutrients within the corresponding assessed ranges (Table 2). The antioxidant activity showed an average value equal to $1.85 \%$ (Fig. 1b) within the experimental domain under consideration. Besides, the antioxidant activities herein (suspension cell culture) were lower than those previously obtained for our group in callus culture with homologous basal culture medium and hormone supplementation, as well as, explant origin $(7.58 \pm 4.07 \%$ ) (Fidemann et al. 2017).

Among the phytochemicals with remarkable antioxidant properties in $C$. baccatum, the red and yellow carotenoids, ascorbic acid and phenolic compounds including flavonoids stand out (Rodríguez-Burruezo et al. 2009). Therefore, the
Fig. 2 Interaction graph saccharose $(A)-\mathrm{KNO}_{3}(C)$ for the adjusted growth index model

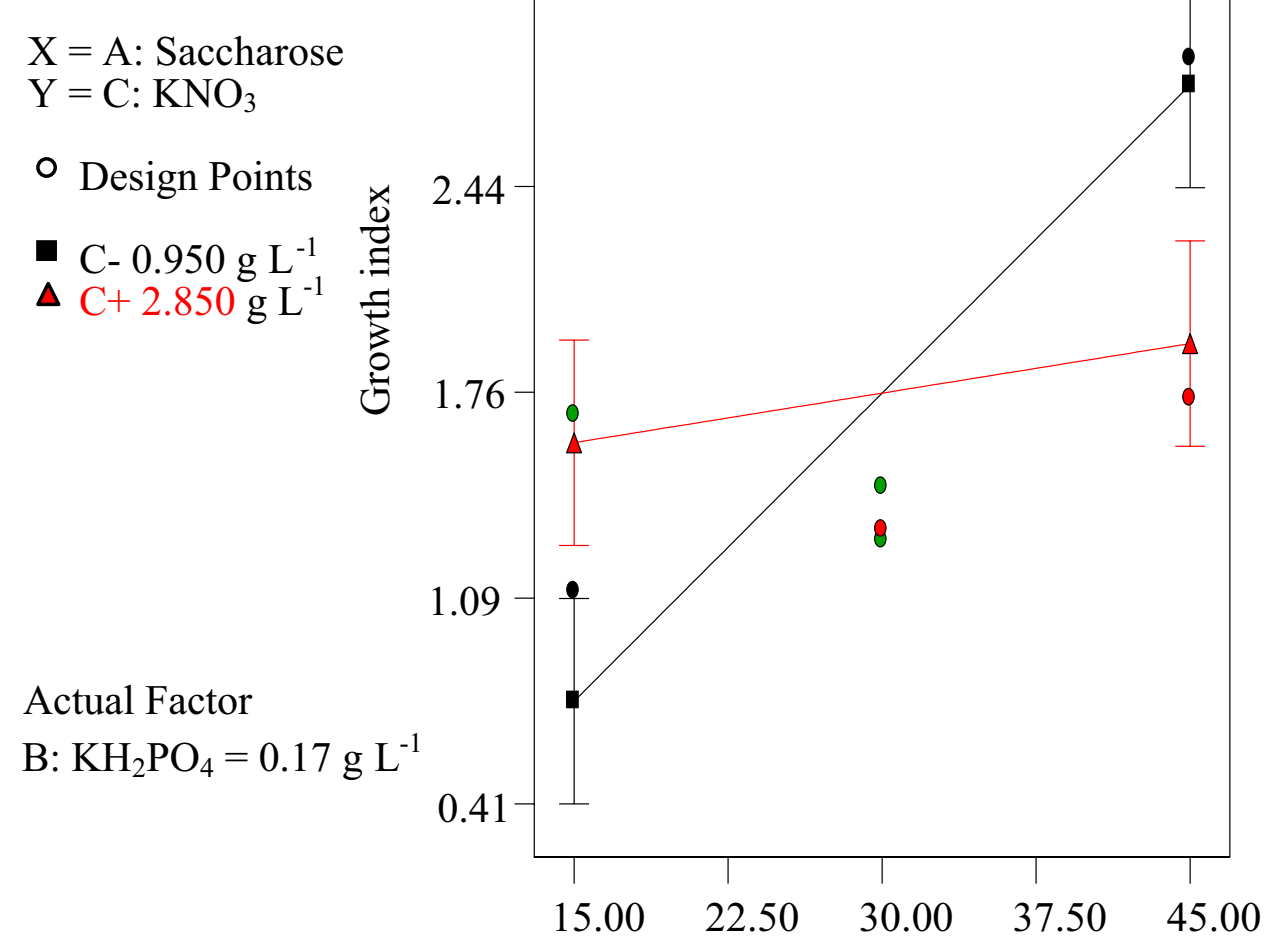

A: Saccharose $\left(\mathrm{g} \mathrm{L}^{-1}\right)$ 
changes in the nutrient composition of the culture medium seemed no affect positively the cell metabolism of Capsicum baccatum $L$. var. pendulum to stimulate the secondary metabolites production with significant antioxidant activity.

\section{Total phenolic compounds}

The phenolic compounds in the extracts showed a similar behavior to the antioxidant activity. Neither, this biochemical parameter correlated to three nutrient concentrations within the experimental region (Table 2). The values of phenolic compounds in the extracts oscillated around $1.69 \mathrm{mg}$ of GAE/g DE. These results were in harmony with previous findings in callus culture of Capsicum baccatum L. var. pendulum for our group $(2.77 \pm 1.19 \mathrm{mg}$ of GAE/g DE) (Fidemann et al. 2017).

The content of phenolic compounds in the assessed suspension cell system was drastically lower than levels for this family of phytochemicals reported for fruit and seeds of Capsicum baccatum $L$. var. pendulum culture conventionally (Zimmer et al. 2012). This confirms the hypothesis that the evaluated changes in culture medium for suspension culture of Capsicum baccatum L. var. pendulum did not improve the secondary metabolism for chemical structures with antioxidant activity. Thus, the chemical stress caused by nutrients in the culture medium, which can induce the activation of secondary metabolism (Yeoman and Yeoman 1996; Davies and Deroles 2014) was not observed in the present work, at least for total phenols.

\section{Flavonoids}

Flavonoids in conjunction with phenolic acids, lignans, and coumestans compose the phenolic compounds, an important class of secondary metabolites with antioxidant activity (Martins et al. 2016). Thus, flavonoids are secondary
Fig. 3 Monitoring of weight loss over the course of suspension plant cell culture (the evaporation of culture medium was considered and removed) caused by cell metabolism (dissimilation curves) (Schripsema et al. 1990). a Run numbers from 1 to 8 (Table 1). b Run numbers from 9 to 15 (Table 1)
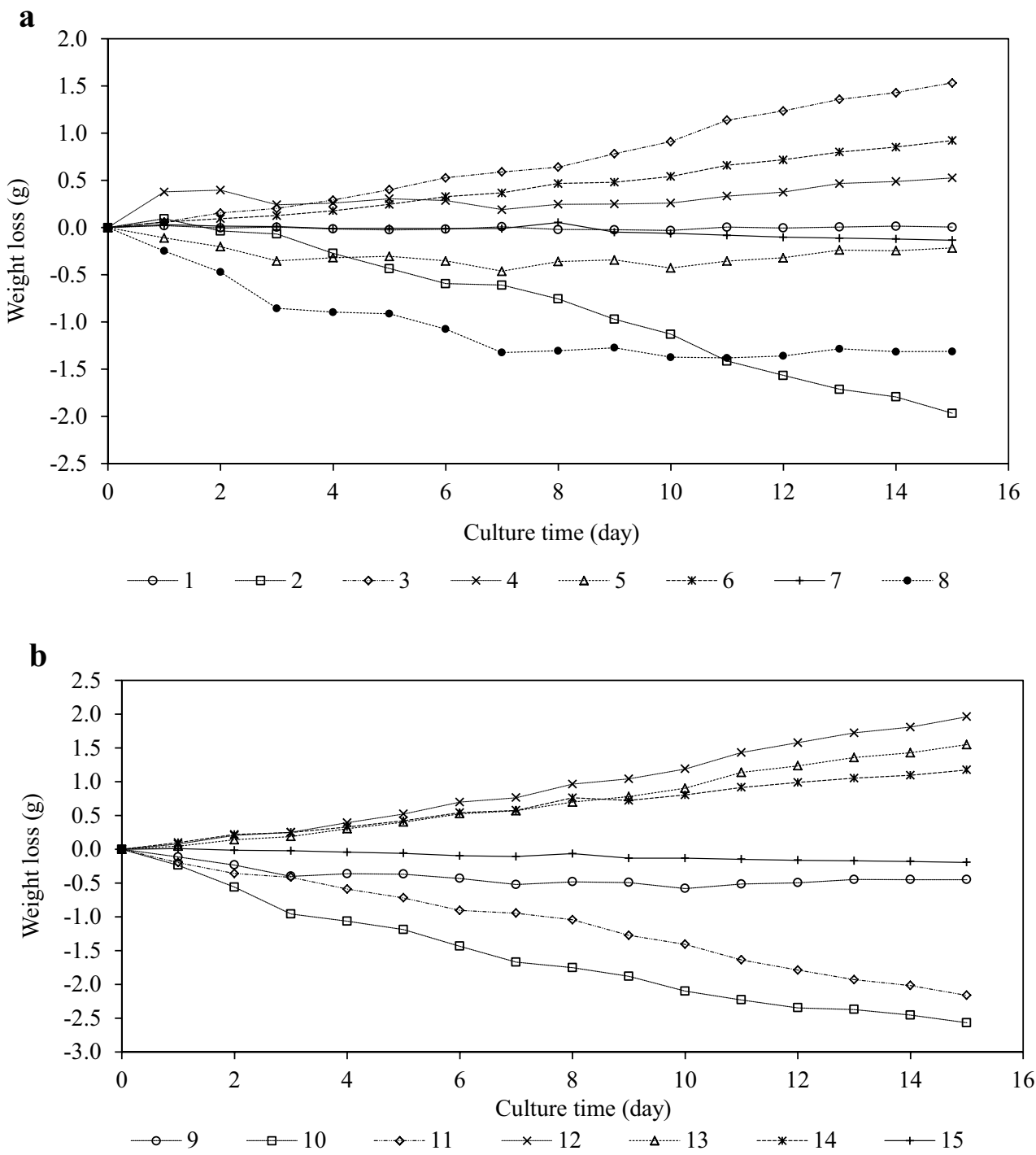
metabolites with wide application in food and pharmaceutical industries.

In this study, the occurrence of these compounds in extracts derived from Capsicum baccatum $L$. var. pendulum plant cell culture was described by a modified twofactor interaction (Table 2). The statistical model regarding coded factors is represented by Eq. 4 .

Flavonoids $\left(\frac{\mathrm{mg} \text { of } \mathrm{RU}}{\mathrm{g} \mathrm{DE}}\right)=0.88+0.35 \mathrm{AC}-0.29 \mathrm{BC}$

The direct relationship between AC two-factor interactions and flavonoids content in extracts demonstrated that relative high flavonoids amounts are obtained when culture medium comprises combinations of high concentrations of saccharose and $\mathrm{KNO}_{3}$, or low concentration of both nutrients (Fig. 4a). Contrary, the significant BC twofactor interactions showed an inverse relationship between $\mathrm{KH}_{2} \mathrm{PO}_{4}$ and $\mathrm{KNO}_{3}$ concentrations and flavonoids. Thus, high flavonoids amounts were observed for high-low combinations of both nutrients in culture medium (Fig. 4b).

The induction of phenolic compounds using nitrate reduction in cellular suspension has been reported for several medicine species (Nicasio-Torres et al. 2012). Despite $\mathrm{KNO}_{3}$ is included in both significant two-factor interactions, the reported individual effect for nitrate was not confirmed in Capsicum baccatum L. var. pendulum cells cultured in Murashige and Skoog medium. Regardless of significant correlation between flavonoids content and nutrient concentrations, the content of flavonoids from suspension culture of Capsicum baccatum $L$. var. pendulum cells was lower than others reported in different parts of the plant (Zimmer et al. 2012; Loizzo et al. 2015).

\section{Optimization}

Two optimization approaches were explored in this work. One of them was addressed to maximize only the cell mass. This approach could be useful to develop efficient cell expansion strategies aiming the scalability of a bioprocess for secondary metabolites production based on Capsicum baccatum $L$. var. pendulum plant cell when other elicitation techniques are utilized to increase the yield of secondary metabolites of interest (Table 3, solution 1). The other optimization approach was directed to maximize the flavonoids yield with Capsicum baccatum $L$. var. pendulum plant cell just by nutrient elicitation (Table 3, solution 2). Maximization flavonoids approach could be suitable to establish a compact bioprocess to obtain valuable compounds of this family of chemical compounds.

The optimal nutrient composition of culture medium for both approaches differed just in $\mathrm{KNO}_{3}$ concentration.

\section{A}

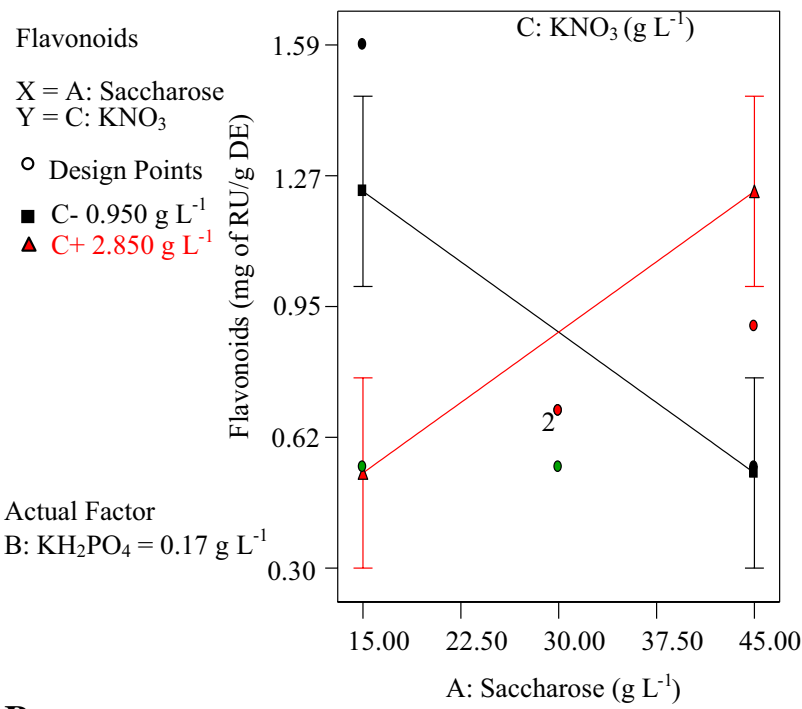

B

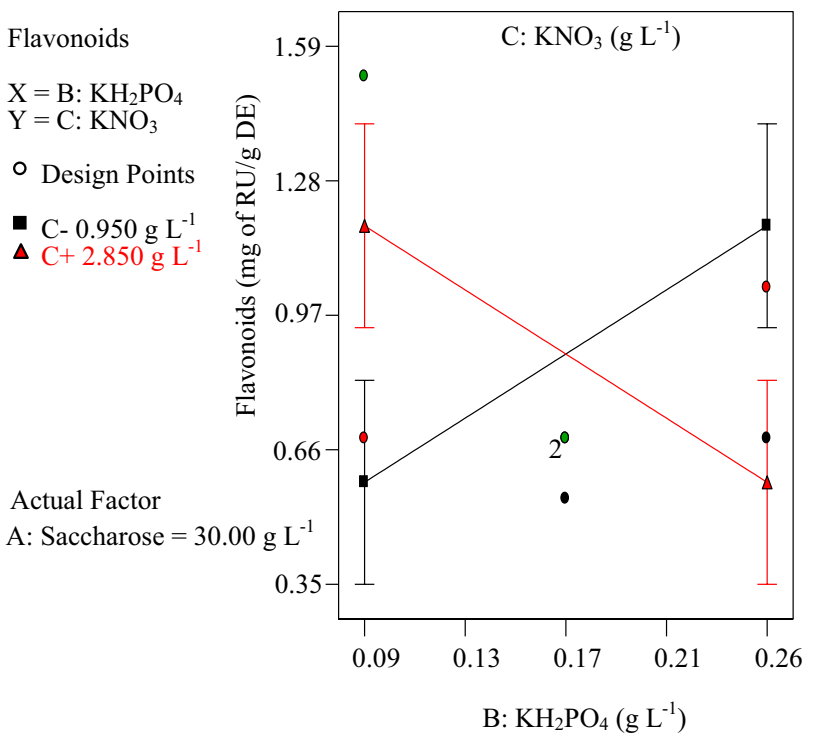

Fig. 4 Interaction graphs for the adjusted flavonoids model. a saccharose $(A)-\mathrm{KNO}_{3}(C)$. b $\mathrm{KH}_{2} \mathrm{PO}_{4}(B)-\mathrm{KNO}_{3}(C)$

For maximizing cell mass concentration, the concentration of $\mathrm{KNO}_{3}$ was the lowest $\left(0.95 \mathrm{~g} \mathrm{~L}^{-1}\right)$ within considered range. Conversely, the concentration of $\mathrm{KNO}_{3}$ was the assessed highest one $\left(2.85 \mathrm{~g} \mathrm{~L}^{-1}\right)$, when maximization flavonoids approach was chosen.

The previous findings are likely caused by the relative high concentrations of potassium and nitrate in the basal MS medium, which was initially developed for tobacco cells (Bhatia 2015). Specifically, potassium concentration, which regulates osmotic potential, at the lowest considered $\mathrm{KNO}_{3}$ level could be suitable for growth of Capsicum baccatum L. var. pendulum cells. Otherwise, at the highest concentration could induce an osmotic stress with impact 
Table 3 An optimized culture medium according to two different criteria using the Derringer and Suich's desirability function

\begin{tabular}{|c|c|c|c|c|c|c|c|c|}
\hline \multirow[t]{2}{*}{ Solution } & \multirow[t]{2}{*}{ Response variable } & \multirow[t]{2}{*}{ Optimization criterion } & \multirow[t]{2}{*}{ Importance } & \multicolumn{3}{|c|}{$\begin{array}{l}\text { Optimal component concentra- } \\
\text { tion }\left(\mathrm{g} \mathrm{L}^{-1}\right)\end{array}$} & \multirow[t]{2}{*}{ Response value } & \multirow{2}{*}{$\begin{array}{l}\text { Desir- } \\
\text { ability } \\
\text { value }^{\text {a }}\end{array}$} \\
\hline & & & & Saccharose & $\mathrm{KH}_{2} \mathrm{PO}_{4}$ & $\mathrm{KNO}_{3}$ & & \\
\hline \multirow[t]{2}{*}{1} & Growth index & Maximum & +++++ & 45 & 0.09 & 0.95 & 3.09 & 0.988 \\
\hline & Flavonoids (mg of RU/g DE) & None & - & & & & - & \\
\hline \multirow[t]{2}{*}{2} & Growth index & Maximum & +++++ & 45 & 0.09 & 2.85 & 2.24 & 0.727 \\
\hline & Flavonoids (mg of RU/g DE) & Maximum & ++++ & & & & 1.52 & \\
\hline
\end{tabular}

${ }^{a}$ Desirability function values next to 1 , and 0 mean a high or low correspondence with the optimization criteria, respectively (Maran et al. 2015)

on flavonoids production. Besides, nitrate ion participates in the synthesis of amino acids (Bhatia 2015). As aromatic amino acids are precursors of phenylpropanoid structures like flavonoids (O'Connor 2015), the increase of $\mathrm{KNO}_{3}$ could be also stimulating directly the flavonoids production through their own metabolic route.

\section{Conclusions}

The influences of three important ingredients in Murashige and Skoog culture medium (saccharose, $\mathrm{KH}_{2} \mathrm{PO}_{4}$ and $\left.\mathrm{KNO}_{3}\right)$ supplemented with 2,4-D $\left(1.138 \mathrm{mg} \mathrm{L}^{-1}\right)$ and BAP $\left(0.228 \mathrm{mg} \mathrm{L}^{-1}\right)$-on biochemical parameters related to the suspension cell culture of Capsicum baccatum $L$. var. pendulum, which characterize cell growth and secondary metabolite yield, were defined. Cell growth was also maximized using a culture medium with concentrations of $45,0.09$, and $0.95 \mathrm{~g} \mathrm{~L}^{-1}$, corresponding to saccharose, $\mathrm{KH}_{2} \mathrm{PO}_{4}$, and $\mathrm{KNO}_{3}$, respectively. Besides, flavonoids yield was maximized with similar culture medium composition, just $\mathrm{KNO}_{3}$ concentration $\left(2.85 \mathrm{~g} \mathrm{~L}^{-1}\right)$ differed. The antioxidant activity and the content of phenolic compounds in derived extracts were not sensitive to the changes in culture medium composition. The results could be useful for developing bioprocesses based on Capsicum baccatum $L$. var. pendulum cells to obtain efficiently secondary metabolites of interest.

Acknowledgements The first author would like to thank Fundação de Amparo à Pesquisa do Estado de São Paulo/Brazil (FAPESP) for Master's fellowship (2014/26997-4) and scientific teams from Laboratório de Biotecnologia Vegetal, Laboratório de Fitoterápicos e Produtos Naturais (FITOLAB), and Laboratório de Bioprocessos (UNESP, Campus Assis). The corresponding author gratefully acknowledges his wife, Relma, and daughters, Giovanna and Paola, for the inspiration to write this manuscript.

Author contributions EGFN, MRB, and RMGS conceived and designed the research. TF, GAAP, TRH, and RBG conducted experiments. EGFN analyzed data statistically and wrote the first draft of the manuscript. All authors contributed to wrote the final version of the manuscript, read and approved the submitted text.

\section{Compliance with ethical standards}

Conflict of interest All authors declare that they have no conflict of interest.

\section{References}

Bhatia S (2015) Plant tissue culture. In: Bhatia S, Sharma K, Dahiya $\mathrm{R}$, Bera T (eds) Modern applications of plant biotechnology in pharmaceutical sciences. Elsevier Inc., Waltham, pp 31-107

Blois MS (1958) Antioxidant determinations by the use of a stable free radical. Nature 181:1199-1200

Chen VCP, Tsui K-L, Barton RR, Meckesheimer M (2006) A review on design, modeling and applications of computer experiments. IIE Trans 38:273-291. https://doi.org/10.1080/07408170500232495

Costa NR, Lourenço J, Pereira ZL (2011) Desirability function approach: a review and performance evaluation in adverse conditions. Chemom Intell Lab Syst 107:234-244. https://doi. org/10.1016/j.chemolab.2011.04.004

Davies KM, Deroles SC (2014) Prospects for the use of plant cell cultures in food biotechnology. Curr Opin Biotechnol 26:133-140. https://doi.org/10.1016/j.copbio.2013.12.010

Dias MI, Sousa MJ, Alves RC, Ferreira ICFR. (2016) Exploring plant tissue culture to improve the production of phenolic compounds: a review. Ind Crops Prod 82:9-22. https://doi.org/10.1016/j. indcrop.2015.12.016

Ferri M, Gruarin N, Barbieri F, Tassoni A (2017) Capsicum spp in vitro liquid cell suspensions: a useful system for the production of capsaicinoids and polyphenols. Plant Biosyst. https://doi. org/10.1080/11263504.2017.1305998

Fidemann T, Nascimento LB, Moraes MC et al (2016) Optimizing in vitro germination of Capsicum baccatum $\mathrm{L}$. seeds through a multifactorial experimental design. Am Int J Biol 4:1-22. https:// doi.org/10.15640/aijb.v4n2a1

Fidemann T, de Araujo Pereira GA, Bossard Nascimento L et al (2017) Holistic protocol for callus culture optimization using statistical modelling. Nat Prod Res 6419:1-9. https://doi.org/10.1080/1478 6419.2017.1380026

Kehie M, Kumaria S, Tandon P (2016) Biotechnological enhancement of capsaicin biosynthesis in cell suspension cultures of Naga King Chili (Capsicum chinense Jacq.). Bioprocess Biosyst Eng 39:205210. https://doi.org/10.1007/s00449-015-1504-6

Lannes SD, Finger FL, Schuelter AR, Casali VWD (2007) Growth and quality of Brazilian accessions of Capsicum chinense fruits. Sci Hortic 112:266-270. https://doi.org/10.1016/j. scienta.2006.12.029

Loizzo MR, Pugliese A, Bonesi M et al (2015) Evaluation of chemical profile and antioxidant activity of twenty cultivars from Capsicum 
annuum, Capsicum baccatum, Capsicum chacoense and Capsicum chinense: a comparison between fresh and processed peppers. LWT 64:623-631. https://doi.org/10.1016/j.lwt.2015.06.042

Maran JP, Manikandan S, Priya B, Gurumoorthi P (2015) BoxBehnken design based multi-response analysis and optimization of supercritical carbon dioxide extraction of bioactive flavonoid compounds from tea (Camellia sinensis L.) leaves. J Food Sci Technol 52:92-104. https://doi.org/10.1007/s13197-013-0985-z

Martins N, Barros L, Ferreira ICFR. (2016) In vivo antioxidant activity of phenolic compounds: facts and gaps. Trends Food Sci Technol 48:1-12. https://doi.org/10.1016/j.tifs.2015.11.008

Murashige T, Skoog F (1962) A revised medium for rapid growth and bio assays with tobacco tissue cultures. Physiol Plant 15:473-497. https://doi.org/10.1111/j.1399-3054.1962.tb08052.x

Murthy HN, Lee EJ, Paek KY (2014) Production of secondary metabolites from cell and organ cultures: strategies and approaches for biomass improvement and metabolite accumulation. Plant Cell Tissue Organ Cult 118:1-16. https://doi.org/10.1007/ s11240-014-0467-7

Nicasio-Torres M, del P, Meckes-Fischer, Aguilar-Santamaría M L, et al (2012) Production of chlorogenic acid and isoorientin hypoglycemic compounds in Cecropia obtusifolia calli and in cell suspension cultures with nitrate deficiency. Acta Physiol Plant 34:307-316. https://doi.org/10.1007/s11738-011-0830-9

O'Connor SE (2015) Engineering of secondary metabolism. Annu Rev Genet 49:71-94. https://doi.org/10.1146/ annurev-genet-120213-092053

Prasad BCN, Gururaj HB, Kumar V et al (2006) Valine pathway is more crucial than phenyl propanoid pathway in regulating capsaicin biosynthesis in Capsicum frutescens Mill. J Agric Food Chem 54:6660-6666. https://doi.org/10.1021/jf061040a

Ramachandra Rao S, Ravishankar GA (2002) Plant cell cultures: chemical factories of secondary metabolites. Biotechnol Adv 20:101-153. https://doi.org/10.1016/S0734-9750(02)00007-1

Rodríguez-Burruezo A, Prohens J, Raigón MD, Nuez F (2009) Variation for bioactive compounds in ají (Capsicum baccatum L.) and rocoto (C. pubescens R. \& P.) and implications for breeding. Euphytica 170:169-181. https://doi.org/10.1007/ s10681-009-9916-5

Schripsema J, Meijer AJ, van Iren F et al (1990) Dissimilation curves as a simple method for the characterization of growth of plant cell suspension cultures. Plant Cell Tissue Organ Cult 22:55-64

Singleton VL, Rossi JA (1965) Colorimetry of total phenolics with phosphomolybdic-phosphotungstic acid reagents. Am J Enol Vitic $16: 144-158$

Smetanska I (2008) Production of secondary metabolites using plant cell cultures. Adv Biochem Eng Biotechnol 111:187-228. https:// doi.org/10.1007/978-3-540-70536-9

Wilson PDG (1987) On-line estimation of biomass using dynamic oxygen balancing. Biotechnol Tech 1:151-156

Wilson SA, Roberts SC (2012) Recent advances towards development and commercialization of plant cell culture processes for the synthesis of biomolecules. Plant Biotechnol J 10:249-268. https:// doi.org/10.1111/j.1467-7652.2011.00664.x

Yeoman MM, Yeoman CL (1996) Manipulating secondary metabolism in cultured plant cells. New Phytol 134:553-569. https://doi. org/10.1111/j.1469-8137.1996.tb04921.x

Zhishen J, Mengcheng T, Jianming W (1999) The determination of flavonoid contents in mulberry and their scavenging effects on superoxide radicals. Food Chem 64:555-559

Zhou X, Zhong J-J (2010a) Plant cell culture, secondary product accumulation. In: Flickinger MC (ed) Encyclopedia of industrial biotechnology: bioprocess, bioseparation, and cell technology. Wiley, Hoboken, pp 3819-3883

Zhou X, Zhong J-J (2010b) Plant cell culture, secondary product accumulation. In: Flickinger MC (ed) Encyclopedia of industrial biotechnology: bioprocess, bioseparation, and cell technology. Wiley, Hoboken, pp 1-29

Zimmer AR, Leonardi B, Miron D et al (2012) Antioxidant and antiinflammatory properties of Capsicum baccatum: from traditional use to scientific approach. J Ethnopharmacol 139:228-233. https://doi.org/10.1016/j.jep.2011.11.005 